\title{
The birth of another rurality
}

\author{
JOSÉ ELI DA VEIGA
}

\section{Introduction}

A

LTHOUGH perhaps unknowingly, every researcher who investigates issues related to rurality is under the influence of either one of two

radical hypotheses about its destiny: total urbanization or a rural rebirth. Nobody has formulated the former in a more adequate way than philosopher and sociologist Henri Lefebvre, in 1970. And nobody has been opposing it in a more convenient way than geographer and sociologist Bernard Kayser, since 1972. After more than 30 years, however, rurality has neither disappeared from the central countries nor has it been born again, which legitimates the option for a third hypothesis that might supersede the first two. This third hypothesis was sketched in a previous work dealing with the issue in the extremely wide scope of the "globalization" process, ${ }^{1}$ and will be reconsidered here in the light of new evidence $^{2}$ and of the vital need for a deeper study of theory.

After a brief presentation of this third hypothesis, the second section of this paper will focus on the exposition of some empirical evidence concerning one of its focal points - the idea that there are three basic vectors of this new rurality, namely: an economic utilization of natural amenities through several activities generally classified under the heading of "tourism"; a biodiversity conservation effort linked to landscape architecture; and an increasing necessity to search for renewable energy sources available in rural areas. After describing the main manifestations of these three vectors for the case of Italy, the second section will also indicate the conflicts - already manifest and anticipated - that may occur among them.

The empirical evidence exposed in the second section necessarily helps to increase the doubts about its theoretical implications, a point that was only touched upon in my first approach to the problem (Veiga, 2004). Accordingly, a kind of Hermeneutics of Lefebvre's and Kayser's hypotheses will be developed in the third section, in a preparation for the conclusion, which in turn will elicit the theoretical rationale supporting the third hypothesis, centered on the birth — rather than the "emergence" — of another rurality.

\section{The third hypothesis}

We want, in our wondrously diverse world, a full spectrum of interactions from near wilderness to near artificiality, but I will seek my aesthetic optimum right in the middle, where human activity has tweaked or shaped a landscape, but 
with such respect and integration that a first glance may detect no fault line, no obvious partitioning...

$\left(\right.$ Stephen Jay Gould) ${ }^{3}$

The most complete triumph of urbanity engenders the valorization of a rurality that is not undergoing a rebirth process, but is rather being born. The most developed societies are increasingly attracted by rural spaces. This new phenomenon has little to do with the relationship established in the past between these societies and such territories. It is an attraction resulting mainly from a vertiginous growth in mobility, with its increasing variety of dislocations, whether long or short, real or virtual. The city and the country got married, and while she takes care of work and leisure, he provides beauty and liberty. ${ }^{4}$ This phenomenon was somehow predicted both by Lefebvre and Kayser, though in shady ways. The "space revolution" that engenders "urban (or post-industrial) society" tends to reinvigorate rurality, but this process does not constitute a presumed "rebirth".

At least two great dimensions of contemporary globalization act in opposing directions upon the destinies of rural areas. The economic dimension - involving production chains, trade and financial flows - tends to act upon rural areas so as to make them more and more peripheral or marginal. Parallel with new regional hierarchies, there are huge territories that become more and more excluded from the great dynamics that stimulating the growth of global economy.

Simultaneously, the environmental dimension - involving both natural amenities and several energy sources, as well as biodiversity — contributes essentially to make rural areas more and more important to people's quality of life and well-being. The simultaneous influence of these two opposing tendencies is generating a double effect upon rurality. On the one hand, it causes that "remote" or "deep" rural area to be increasingly preserved, though admitting of several low impact economic activities. On the other hand it promotes, in the "near" or "accessible" rural area, the emergence of unheard of socioeconomic arrangements.

In the most dynamic rural territories, activities belonging to the tertiary sector prevail, mainly services attracting income generated by the productivity of other places. Consequently, a greater rural dynamism in advanced societies is based on activities related to second residences, retired people, extreme sports practitioners, congress attendants, tourists and students. And what generates the most jobs is local health, culture, education, sports arrangements, as well as several other types of recreation or tourism. ${ }^{5}$

Manifestations of this new rurality in Europe and North America do not result from an impulse supposedly resurrecting the foundations of some ancient rurality, even though they can exist side by side with aspects of continuity and permanence. What is new in this rurality has little to do with the past, for there have never been societies as affluent as those which today value so much their relationship with nature. This is true not only in what concerns the awareness of threats to biodiversity or to our planet's thermal regulation, but also regarding 
the freedom conquered by retired people to choose the best natural remnants as a place of residence, or the freedom of many social categories to spend their free time out of - and sometimes far away from - the urban agglomerations where they live and work.

In the few lines above the third hypothesis was summarized, but there are several key-statements that need more accurate and specific testing. One of the most important points is the idea that the environmental dimension of globalization tends to make rural areas more and more important to people's quality of life and well-being, through the influence of a sort of trinity: conservation of natural resources, efficient economic utilization of the amenities resulting from this conservation, and exploitation of new energy sources. We should, therefore, examine the evolution of these three vectors in the specific case of Italy and then discuss their interrelations.

\section{The three vectors 6}

Italy offers plenty of evidence confirming the three main vectors part of the hypothesis of the new valorization of rurality. The case illustrates very well how these vectors are manifested in an evident progress towards cultural and biological diversity, economic utilization of the resulting amenities, and some forms of renewable sources of energy.

A very strong indication of rural tourism's growing relevance in the last decades was the seminar on the subject held by the Touring Club of Italy in the end of 1989. On approaching "the values of rurality in today's world", the scientific consultant to the event, geographer Umberto Bonapace (2001), emphasized the occurrence of a deep "historical change, simultaneously economic, social and anthropological". A mutation characterized by the demise of the peasant civilization and the emergence - still vague and indistinct of a new culture with an urban profile which, in turn, has lost its old cultural specificities so as to adjust to the alien models of the so-called consumer society. Wondering what would be left of rurality in that country, and what worth it could still have on the eve of the year 2000, Bonapace proposed the following answer: two great heritages remain that must be managed and taken advantage of for the present and the future. The first - of a physical order — is space; the second - of a cultural order — is the legacy of tradition. And, with the help of a soil use map, he demonstrated that rural areas unexploited for agriculture, or used only extensively - where obviously the lowest demographic densities are observed - correspond to four fifths of the national territory. Nor would it have been necessary to add that the other fifth, where the great intensive agriculture is predominant, is highly urbanized and industrialized (ibidem).

In his turn Corrado Barberis (2001), president of National Institute of Rural Sociology, started his speech by indicating that there is a "repopulation" trend in the seven thousand rural municipal districts, a phenomenon that he ascribed to six factors: a) a higher birth rate, which has yielded a positive 
demographic balance; b) an increase in mobility thanks to an improvement in transportation systems, which has multiplied the pendular movements between home and workplace; c) an incipient urban exodus caused by the high price of rents and environmental degradation, phenomena which have highlighted certain advantages of life in rural areas, where everyone - or almost everyone, even workmen - has his own house; d) a decentralization of companies, attracted by the offer of land - not only cheaper, but also tied to good financial incentives; d) a kind of local entrepreneurship, often of an agricultural origin, especially in areas where partnerships and co-ownership (mezzadria) are dominant; f) the regional policies promoted by the Constitution of 1947, but that only began to materialize in the 1970s, with the autonomy conferred upon new entities focused on agriculture, handicraft, tourism and, above all, urbanism.

It has been the joint influence of these six factors that generated a "new rurality", Barberis stated. In other words, a social system in which agriculture often generates the smallest part of the income, with little influence on the GNP of the territory considered, but which guarantees a set of fundamental infrastructures allowing people to: have their own house, enjoy a less limited space and eat healthier and more inexpensive food. This "new rurality" is stronger in regions of the Central North of the country, where there has been a remarkable establishment of small companies dedicated to handicraft and manufacturing. And local fairs and festivities are the places where this new rurality has its strongest expression, often related to the local patron saint, but also, in a less explicit form, to the gastronomical deity of the place: "il raviolo o la bruschetta, il pecorino o il cinghiale". Such manifestations are marked by a strong sense of belonging, which supports small local markets dedicated to this or that typical product. And here is a very important consideration concerning tourism and agriculture as well: In order for a typical product to gain national recognition, it has to be the symbol of the local culture.

Italy is Europe's leading country in organic agriculture (there it is called "biological"). And it occupies the third top place in the world, next to Australia and Argentina. In today's world the area cultivated using ecologically responsible alternative methods is estimated to be under $0.5 \%$ of the whole rural area, and in Europe this participation is higher than $3 \%$. In Italy, the 55,902 "bio" establishments already amount to $7 \%$ of the national agricultural area. Also concerning the issuance of certifications for typical products, Italy occupies the topmost place in Europe. And 14 out of the 20 regions have declared to be "GMO free".

Despite its tiny size (1/30 of the continent), Italy owns half of Europe's flora and one third of its fauna, besides being the European country with the greatest biodiversity. Furthermore, the available information on its protection systems for green areas allows us to estimate that several types of conservation practices are under way in more than one fifth of the territory.

Firstly, almost $11 \%$ of its surface integrates the most traditional system of conservation units, such as parks (national and regional), natural reserves (state and 
regional), marine conservation areas, and other regional natural areas (on the whole about 4 million hectares). But obviously these $11 \%$ are the result of great regional contrasts. The participation may be over $20 \%$ in regions with many mountain areas, which perhaps have been benefited by a sort of natural defense against the millennial aggression of human activities. Or it can be at the minimum level of $5 \%$ or $6 \%$ in widely known opposite cases, such as those of Veneto and Lombardy. However, this does not seem to be a rule, for in Liguria the proportion is similar, although the relief is also inappropriate for agricultural activities, ${ }^{8}$ and the fact that this is the region with the proportionally largest forest cover $(73 \%)$.

Secondly, some $15 \%$ of its territory integrates a more recent system, resulting from incentives established in the program "Natura 2000", funded by the European Union. Besides these two arrangements directly focused on biodiversity conservation, it is also worth mentioning the whole forest cover, which includes commercial exploitation. And on this topic there are really impressive data, supplied by the Forest Inventory for the period 19852003. During this 18-year period, a retraction in the most extensive forms of agricultural and cattle raising activities allowed for the forest cover to grow $21.8 \%$, from 8,360,100 hectares (in 1985) to 10,184,458 hectares (in 2003). And it cannot go without mentioning that these 10 million hectares or so of land correspond to about $29 \%$ of the national territory.

In central European countries the contribution of renewable sources to the production and use of energy is still insignificant. But governments are suffering a growing pressure to create policies favoring such renewable sources, both because of an uncertain long-term perspective concerning fossil sources and other factors, among which it is worth mentioning the implementation of the Kyoto Protocol. In the European Union, this strategic effort has been strengthened as of 1997, with the "White Book", and even more reinforced around the end of the year 2000 with the "Green Book", entitled "Towards a European strategy for the security of energy supply".

Nonetheless, real advances have been slow and fairly irregular among the countries. Outstanding examples are countries like Germany in the area of wind and photovoltaic energy; Spain and Denmark in that of wind energy only; Greece and Austria in solar thermal energy; while no country deserves any mention in the field of biomass. ${ }^{9}$ Italy is even behind the above mentioned countries. Even so, in the field of renewables of that country there are companies that export technology, as well as two emblematic examples of energy self-sufficiency: the city of Bolzano, in Trentino-Alto Adige, and themunicipality of Varese Ligure in Liguria. As to what refers specifically to the utilization of biomass for the production of biodiesel and ethanol, Italy follows the European trend in an honorable third place, after France and Germany. However, part of the colza utilized for biodiesel production must be imported from these two countries.

It is also very important to notice that if the efforts for the preservation of diversity, as well as their consequences in the realms of culture and landscape, 
contribute a lot for the expansion and consolidation of several forms of rural tourism, the same does not apply to the exploitation of renewable sources of energy. At the same time, the most outstanding cases of tourism-supported rural development do not guarantee the long-term duration of several forms of natural amenities utilization. And these natural amenities may be even hostile to any kind of new renewable energy source exploitation involving some sort of landscape degradation. ${ }^{10}$

In other words, even if the three vectors bear out the unmistakable birth of another rurality, we should not, lest we be too naïve, suppose that they converge to the same point. On the contrary, these first years of the 21st century may reveal also the emergence of a new kind of conflict in rural territories of the most modern regions in central European countries. The most obvious case is certainly that of wind energy, which already incites a heated debate in the very heart of the environmental movement. At present, they have a "muro contro muro", that is, an unbudging situation. On one side, as advocates for the wind installations are: the government, the most important environmental associations (Legambiente and WWF, World wide Fund for Nature) and many municipalities. On the other side, worried over landscape impacts, are some regions (Veneto, Puglia, Sardinia), the organization "Italia Nostra"11 and several other environmental entities, among them Mountain Wilderness. In 2005, WWF requested of the Ministry of Cultural Heritage and Environment the publicizing of guidelines about the criteria for the location of installations. It also announced the publication of a joint document with Anev (a producers association) with the purpose of demonstrating that wind energy utilization and nature conservation are compatible. It was an agreement that came to be considered "historical" (Cianciullo, 2005a).

Regional presidents, however, together with "Italia Nostra", an important entity, insist on the necessity of a moratorium that may allow an examination of "where, how, and when". Meanwhile, the most radical conservationists argue among themselves provoking a kind of account adjustment within all associations. Even so, an agreement is likely to be reached, avoiding a more serious confrontation between the regions that have blocked the wind building sites and the central government, which has obtained from the State Council a declaration of unconstitutionality of the anti-wind bill enacted by Sardinia.

Even more serious have become the conflicts resulting from the tourist saturation in some rural regions of Italy. Suffice it to say that, in a report issued by the Organization for Economic Co-operation and Development (2002, p. 159-82) containing a true picture of the successful experience of the Tuscan province of Siena rural development, serious doubt was cast on the possibility of its tourist pattern being "long-standing", or even "viable".

The province of Siena has enviable landscape, gastronomic and thermal treasures, as well as its widely known and searched for artistic and historic attractions. Consequently, the region suffers from tourist saturation, which 
causes economic, social and environmental negative effects. An excess of tourist activities not only generates a feeling of resentment and rejection within the local population, but also frequently causes an eviction effect, since the historical centers progressively lose their traditional population and function. The increase in rent and landed property prices generates distortions that force the local people to search somewhere else for a more accessible dwelling. This phenomenon also provokes a change in trade, so that the traditional houses are replaced by shops for tourists. On the other hand, visitors searching for authenticity tend to avoid these saturated places, where everything begins to seem fake. An excess in the flux of visitors, with the ensuing excessive number of small souvenir shops only contributes to chase away the best customers, after debasing the cultural and/or natural inheritance image that caused the attraction in the first place.

Another aspect of tourism which ultimately has a rather negative impact on the landscape, besides biodiversity erosion, is certainly the proliferation of the "second residence", especially in the neighborhoods of protected areas, often lacking respect for the legislation, but often ending up with the benefit of some sort of pardon or amnesty. This kind of real estate speculation, which has stirred up the debate about the "abusivismo edilizio", is linked to a period of explosive growth of the building industry in general (since 1994), historically matched only by the post-war period between 1951 and 1965. Investments in this sector increased 9.4\% between 2001 and 2004, while the GNP grew only 3.6\%. Under such circumstances, there has obviously been an excessive amount of illegalities and predatory real estate speculation, especially in landscape patrimony areas, the most attractive for tourism investments (Legambiente, 2005a).

It must be also remembered that there is an enormous institutional inertia that makes the European Common Agricultural Policy (CAP) reform very slow. This factor is certainly responsible for the continuing of agricultural practices that hardly contribute to what we have here called the three vectors. And European and national policies aiming at stimulating activities that are characteristic of the new rurality count on insignificant budgets as compared to traditional agricultural policies focused on production, beginning with CAP.

Even in rural regions that are able to develop mainly through new activities linked to the amenities (in general classified simply as touristic), it is common to observe that the main part of the cultivated land will only be achieved because of the subventions from CAP which, paradoxically, favors specialized productions, or "monocultures". This problem has been characterized as a true "dilemma" (OCDE, 2002, p. 13). Besides, a great mystery is the impact of the use of the biomass as an alternative source of renewable energy, in case it comes to gain some relevance in the future. If there is a gradual conversion of CAP into a policy encouraging new energetic options, perhaps its negative impacts on the other two vectors - biodiversity conservation and tourism - will grow excessively. However, if future difficulties in the field of energy generate incentives to specialized cultures other than the ones already protected by 
CAP, certainly this will give rise to conflicts which, for the time being, are still imperceptible.

One of the strongest characteristics of Italian rurality is the contrast between rural spaces whose economy still depends essentially on incomes obtained with the exportation of agricultural (or agroindustrial) products and areas where the economy depends essentially on the displacement of incomes generated and obtained in the cities. This separation usually has a certain correspondence with a geophysical characteristic, related to relief. To one side, plains and plateaus, to the other side, hills and mountains. Even in cases where the focus of tourism displacements is hydrographic - as in the case of lakes it is almost always combined with nearby hills (or grassy hills) and mountains.

This does not mean that rural territories belonging to the great plain agriculture cannot enjoy some tourist exploitation. Neither does it mean that rural areas that offer natural amenities do not benefit from incomes deriving from the sales of primary products. On the contrary, suffice it to remember the several forms of historical and cultural heritage that are present in the plains, or the countless types of traditional agricultural or quality products that are typical of the hills and mountains. Moreover, there has also been a substantive green area protection on the plains (especially the banks of rivers crossing them), and some forms of intensive horticulture are practiced in hilly areas.

Despite the existence of all these intersections, it seems certain that a configuration of two very distinctive subsets of rurality has been established: one of them is essentially marked by the great agriculture of the wide plains, and the other is essentially market by the natural amenities of the more bucolic landscapes found in areas of mountains and hills. And such geographic division seems to have been directly influenced by the evolution of this variety of phenomena generically named "tourism", which in turn is strictly determined by a simultaneous increase in free time and income, and, accordingly, also an increase in leisure activities for more and more different social levels.

It was only in the interwar years that paid vacations were obtained by unions representing the biggest professional categories in most countries nowadays considered developed. Only after its generalization, during the Golden Age (1948-1973) did the so-called mass tourism explosion occur, with the emergence of today's migratory currents of retired people. For that reason, it was mainly from the 1960s onward that spending free time in a country house, or in several kinds of natural protected areas, has become a real possibility to large sectors of today's immense middle-level layers of European central countries (Battilani, 2001).

\section{The meanings of Lefebvre's and Kayser's hypotheses}

First of all, it is essential to clarify the general difference existing between these two hypotheses and another one, much more common, embedded in the generalized use of the expression urban-rural "dichotomy", ${ }^{12}$ mainly because 
they correspond to entirely different ways of thinking. A dichotomy is a division in two branches or the division of a genus into two species that absorb the totality. It is a classification which divides each thing or proposition into two, and each of these is in turn subdivided into other two. The concept of dichotomy obviously corresponds to the purest analytical reasoning that cuts, decomposes and separates in order to reach a better definition (Marcondes, 2004). It certainly has the advantage of clarity, since it explicitly enumerates the discrete aspects of a logical subject.

However, in dialectical reasoning, a tradition to which the hypotheses of Lefebvre and Kayser belong, analysis is only and solely the first moment, since its purpose is dealing with totalities. For this reason, its main idea is not dichotomy, but the unity of opposites. It is perfectly possible to see these two ways of thinking — the analytical and the dialectical — as mutually complementary rather than excluding, although reverse understandings have been also common. For example, the understanding of those who participate in a dispute over Positivism in German Sociology, as it is clearly observable in Adorno (1999). But much more productive seem to be the open contributions favoring an approximation between Neo-Platonic and Aristotelian currents. ${ }^{13}$

Undoubtedly, for the general opinion, the terms dichotomy, duality, opposition of contrary poles contrast or simply contradiction may even seem synonymous. However, as we know, the notion of contraries, obscurely expressed by the word "contradiction", has always been something very different, in Western and Eastern Philosophy as well. The notion of contradiction originated dialectic thinking, which only started achieving some consistency less than 200 years ago with Hegel. And it remains as a very lively logical-philosophical culture, despite all the confusions generated by the $20^{\text {th }}$ century modes of Marxism, and by so many other perversions imposed by several modes of totalitarianism. It was within this context and within this intellectual tradition that the hypotheses of Lefebvre and Kayser appeared.

\section{The impetuous Lefebvre}

Lefebvre proposed the concept of urban society for the post-industrial society, that is, that which is born from industrialization and succeeds it. And by urban revolution the author means the set of transformations undergone by contemporary society as it leaves behind a period when issues related to growth and industrialization predominate, to step into a period when urban problems will definitely prevail. In other words, a period when the search for solutions and modalities belonging to urban society will occupy the center of the stage (Lefebvre, 2002, p. 16).

At the end of his 1970 book, The Urban Revolution, the author warns us that it was as a hypothesis that he anticipated the concept of urban society since the first page. But that concept should not be taken as finished. To claim it would be tantamount to being dogmatic. It would be the same as inserting this concept 
into an epistemology that should be put under suspicion, since it is premature and places the categorical above the problematic, and also because it hinders - and perhaps deviates - the movement that raises the urban phenomenon to the knowledge horizon (ibidem, p. 151).

Four years later, in the 423 pages of the book The Production of Space, which was the climax of an intensive phase of intellectual investment in Urban Sociology (1968-1974), there is no reference to the 1970 book, and very rare and the most indirect are the allusions to a hypothesis of complete urbanization. In its place, Lefebvre mentions a "space revolution" that — in parenthesis — would supposedly subsume the "urban revolution", in a way analogous to that of the great peasant (agrarian) and industrial revolutions (Lefebvre, 1995, p.419).

These passages make it clear that the great philosopher and sociologist Henri Lefebvre (1901-1991) manifested a strong tendency to interpret the historical opposition between urban and rural phenomena (or between city and country, as some would prefer) as an antagonistic or irreducible contradiction. In this kind of contradiction, in which the poles are asymmetrical and incompatible, one of them must necessarily eliminate the other. After the domination is reversed, there begins a qualitatively new phase.

In the West, the end of the rural domination over the urban occurred in the last decades of the $12^{\text {th }}$ century, a fact that was analyzed in several manners by at least three great historians: Carlo M. Cipolla (1993), Georges Duby (1973) and Jacques Le Goff (1992). In case this contradiction should be interpreted as an antagonistic contradiction, there will be a tendency to suppose that the rurality pole will end up by being eliminated by the urban pole, even if it takes many centuries or even millenniums. As a rule, the simple expression "urban society" already implies a process in which the pole that has ceased to dominate tends to disappear.

The inclination to interpret contradictions of historical nature as antagonisms should not be considered a particularity of Lefebvre's thinking. After all, this has been one of the main characteristics of the most diverse forms of Marxism. And there is no doubt that the origin of this way of thinking the great historical contradictions is present even in the work of Marx, specially in the texts that most reveal the ascendancy of the revolutionary utopian over the social scientist, according to the refined interpretation of his work made by Guido Carandini (2005). It occurs, nevertheless, that two other kinds of contradiction are also part of that philosophical project taken over by Lefebvre since the end of the 1920s, when he discovered Dialectics, with its concepts of sublation (dépassement, aufhebung) and of totality (Hess, 1988, p. 75). Two kinds of opposition that certainly have been neglected in his vision of a possible "urban revolution".

Delving into the functioning of the Capitalist economy, Marx also detected non-antagonistic oppositions, in which the contraries are in a logical position of asymmetry. In such cases, there is neither an innovative elimination 
of one of them nor the "synthetic" sublation of both, but a kind of cyclic, or undulatory, reproduction of the basic position. Lefebvre also detected another situation, in which the opposition of contraries engenders something essentially new. That is, he identified three kinds of opposition that may be understood simply as determinant of revolutionary, undulatory and embryonic processes. ${ }^{14}$

In view of this, the criticism to Lefebvre's hypothesis made in Veiga (2004) must be more rigorous and precise. Indeed, the reduction of the rural to the agrarian has only reinforced Lefebvre's structural inclination to think the urban-rural contradiction as an antagonism. Thus, it is not a question of a simple "misunderstanding", since all the contrary empirical evidence may very well be interpreted by those who agree with Lefebvre as mere ephemeral anomalies of a slower process of demise of rurality.

\section{The coy Kayser}

Would it not, therefore, be sensible to conclude that the evidence presented in the second section of this article confirm the idea of "rebirth" utilized by Kayser? The answer is no and for two very different reasons. Firstly, because of the comparison between the already described facts and those which deserved more attention in the main contribution of Kayser to the subject, La Renaissance Rurale: Sociologie des Campagnes du Monde Occidental (1990). Secondly, because of the discussion of the meanings that this strange notion of "renaissance" might have for the history of human societies.

Kayser's starting point was a rural space demographic change in the majority of industrialized countries during the 1970s. After decades (sometimes a whole century) of decline, the rural population curve showed a recovery. Although not very noticeable, the break with the previous tendency was clear: American sociologists and demographers were right in qualifying this inflection as a "turnaround", or "retournement" (Kayser 1990, p. 47).

After analyzing the manifestations of this demographic phenomenon in Great Britain, Germany, Holland, Italy, France and the United States, Kayser starts a deeper examination of the last two cases stating that among American authors the expression "rural renaissance" was more successful than "counterurbanization". And he concludes this chapter with a "general hypothesis", based on Cloke's proposal (1985) to explain the cases in Great Britain, the United States and New Zealand. ${ }^{15}$ Availing himself of this general hypothesis, Kayser proposes to "go further" in the identification and evaluation of interactive factors found in the contact zones between local and global. He then comes to the following formulation:

The growth resumption in the rural world taken globally, as observed in villages and small towns, is the result of the diffusion in space of the effects of modernization and enrichment of society as a whole. (Kayser, 1990, p. 81, emphasis added $).{ }^{16}$ 
The author's characterization of rural renaissance was presented in the four following chapters, dedicated to four dimensions: 1) "old and new peasants", 2) "the rearrangement of the village society, 3 ) territorial organization: the location discovered", 4) "the village culture". And the conclusion starts with a paragraph that could not be more relevant to the aims of this comparison:

Analyzing the contemporary mutations registered in country sites around the Western world, this book provides a verification of what was at first only a hypothesis of an attentive observer: renaissance. The expression was not coined by some poetic imagination: it is taken from the present scientific American literature. Furthermore, we ourselves had already naively used it in 1972, in a joint article on the new threats caused by the extension of a military camp over the plateau du Larzac. (ibidem, p. 289, emphasis added). ${ }^{16}$

In a comparison between the three points emphasized in Kayser's analysis and what was called above "the three main vectors" of the present valorization of rurality, it may seem that the two views raise completely different issues. There is a hint that in 1990 Kayser was also still being held prisoner of an agrarian view of rural space interpretation, as demonstrated by the notions of "new peasants", "village society", or even "village culture". Not that these phenomena have disappeared from present rurality in the most developed countries. But this permanence only reminds us of that biological verification according to which every organism carries the remnants previously functional structures, as the rest of different ancestral states. Among them, bones hidden inside the skin of some whales, or remainders of pelvic bones found in some serpents, traces of their limbed ancestors.

Besides this obvious contrast, that does not lessen the importance of Kayser's contribution - since the "three vectors" could not be distinguished in the 1980s - we must discuss, then, what meaning the notion of "renaissance" may have for the history of human societies.

The idea of "renaissance" is acceptable to characterize a cultural movement of transition between two ages, whose distinguishing feature is the rescue or recuperation of ancestral or atavistic values and ideas. This does not mean, nevertheless, that this metaphor may be transferred to the realm of material civilization, an expression that implies at least society and economy. Therefore, even if the use of the expression "renaissance" may have had success in American scientific literature - and even if it thrilled an analyst as excellent as Kayser - it is essential to remember that the idea of renaissance is so alien to Economic and Social History as it is to Natural History. As what is new always springs from what is old, it will always be possible to identify in the former these remaining traces. But they only acquire some meaning as products of an evolution. This is the principle that must govern every analysis of any type of historical series, and not only those of natural history. Hence the importance of the theoretical basis separating the hypothesis of this work and that of Kayser's. 
There is a fundamental ambiguity in his work. On the one hand, he adheres to the use of the term "renaissance" that was being adopted by the American scientific literature. But, on the other hand, between the formulation of the general hypothesis and the conclusion, he prefers to say that contemporary "mutations" have been caused by the diffusion in space of the effects of modernization and enrichment of society as a whole. A more sensible idea, we must admit, although the theoretical problem of his hypothesis must be identified in this very ambiguity.

After all, a mutation is a phenomenon in which new genetic variations are offered to selection. In any of the several Darwinian interpretations, it is always understood as a random occurrence. And if Darwinists make such a fuss about the accidental, casual, fortuitous, uncertain or occasional character of mutations, it is exactly in order to establish a clear contrast with the other side of the evolution process: the selection pressures.

Emphasizing the fact that mutation may be fortuitous is our way of calling attention to the crucial truth that selection is sublimely and quintessentially non-aleatory. It is ironic that the emphasis on the contrast between mutation and non-casualness of selection has led people to think that the whole theory is made of chance. (Dawkins, 1998, p.94, emphasis in the original)

Obviously, one may always argue that the metaphorical use of the word "mutation" should not demand of Kayser the intention to express any type of coherence with Darwin's theory of evolution. But one can also suppose that this is merely one of those false steps, or lapses, that help uncover the theoretical problems underlying interpretation. Kayser's "general hypothesis" (ibidem, p. 81 ), is that rural growth resumption is the effect of the diffusion in space of the effects of modernization and enrichment of society as a whole. And his conclusion (ibidem, p. 289) is that "renaissance", which was originally only a hypothesis of an attentive observer, was verified through the analysis of contemporary "mutations" registered in the fields of the Western world.

That is, for Kayser, the mutations that characterize such "renaissance" would have been the result of circumstances created by the effects of modernization and enrichment of society as a whole. Strictly speaking, one can even admit the reverse: That among countless random mutations only some are being selected by the more general process of society as a whole. And even if no importance is attached to such a mistake underlining the idealist dimension of the idea of "renaissance", one can still see it as a rhetorical device of the second interpretation type of the urban-rural contradiction, which is non-antagonistic, and does not eliminate one of the extremes, but is rather the undulatory reproduction of the basic opposition. After decades of rural decay, there appear signs of something different, but that would not be a real novelty. Besides, perhaps right here is the explanation for the fact that Kayser does not explicitly oppose his hypothesis to Lefebvre's. 
On the contrary, he prefers to suggest that it is all about rescuing a much earlier Lefebvre's, expounded in $1949 .{ }^{17}$

The greatest similarity between Kayser's vision and the rural Sociology Lefebvre had elaborated between the early 1940s and the mid-1950s is the supposed centrality of the "peasant community". In the opening pages of his book, Kayser explicitly states that rurality as a particular mode of utilization of space and social life presents four characteristics: a) a low demographic density related to the predominance of vegetation covered landscapes; b) a mainly agrosilvo-pastoral economic use; c) the inhabitants' way of life, characterized by a belonging to groups of limited size and by their unique relationship with space; d) a specific identity and representation, strongly marked by the peasant culture. And more than half of his book was dedicated to a description of "ancient and new peasants", a "recomposition of the village society" and the "village culture".

In short, giving more attention to empirical evidence allowed Kayser to be led - even if he would not admit to it clearly - to a hypothesis that is the reverse of Lefebvre's. But it exhibits an incongruous theoretical basis, for the idea of "renaissance" can not in any way be similar to the idea of "mutation". In using such expression in a metaphorical way to refer to the history of the urban rural contradiction, he unintentionally admitted - certainly in an unconscious and subliminal way - that indeed something new is emerging, and not that something old could be returning, or reappearing.

Two important elucidations are, at this point, absolutely necessary. The first is about the approximation being suggested along the last paragraphs between reflections originated in the Natural Sciences and those coming from the applied Social Sciences. This is not a "naturalistic" illusion, an inclination of someone who supposes there is no significant difference between these two realms, and thinks that the latter should imitate the former. On the contrary, what is presupposed here is that changes in the development of the Human Sciences have a Lamarckian rather than a Darwinian character. Societies live in a symbiosis with their cultures, which authorizes the knowledge and experience acquired by the older ones to be directly transferred to those succeeding them. Hence the high frequency with which there is progress in socioeconomic, sociopolitical and sociocultural changes, a phenomenon entirely strange to Natural History. This does not mean, however, that one should not search for coherence between the forms of logical reasoning (both dialectical and analytical) and the facts of nature. In other words, the illusion would dwell in assuming the possibility that Social Sciences could be make an entirely arbitrary use of biological notions employed as metaphors.

The second elucidation is about the term "emergence". People who really pay attention to and carefully observe the empirical evidence of the present European rurality usually prefer the term "emergence" to the term "renaissance", even without disagreeing with Kayser. An excellent contribution in this respect 
was given by Nazareth Wanderley (2000). When not used to express urgency, or an immediate necessity, the word "emergence" always denotes a sense of novelty.

In contemporary scientific debates, however, this term has acquired, since the last third of the $12^{\text {th }}$ century, a very different meaning. Particularly in the realm of research about "complexity", the term has been used to designate a set of new scientific concepts resulting from transdisciplinary approaches. Being inaccurate, the term is of course subject to several interpretations. Nonetheless, in the field of Physics and Mathematics, as well as in Chemistry and Biology, there is a narrower understanding, which has been under intense scrutiny, called NDS: Nonlinear Dynamic Systems. ${ }^{18}$

The theory aims to describe space-time changes in the field of systems, on account of the causes of these changes. Such systems may be sets of molecules, or sets of living species forming populations, whenever they are interacting. And they are characterized as "nonlinear" whenever in the interactions among their components there is no proportionality between causes and effects (changes). When nonlinear interactions exist in some dynamic system, their behavior acquires new characteristics, sometimes strange, often unexpected, and generally counter-intuitive, besides being "disturbing" to any kind of interpretation or approach accustomed to linearity.

Complex systems seldom reach an equilibrium. Generally they are in stationary condition of non-equilibrium. For example, concentrations of different chemical substances in a certain volume may perfectly remain constant while numberless chemical reactions either consume or produce them. In the non-equilibrium stationary condition, all these processes compensate for one another. But if some of the relevant system's parameters are altered, however slightly, the stationary condition also changes. And in nonlinear systems there may occur a new phenomenon, starting from a parameter value considered "critical". The previous stationary solution ceases to be stable and the system evolves in the direction of one (or several) other possibly very different solution(s). This is what NDS theoreticians call "bifurcation". There are several types of bifurcation that reflect the qualitative behavior richness of the NDS. And the importance of these bifurcations in Nonlinear Dynamics dwells in the renovation they bring to the explanation of emergent phenomena.

In a nutshell, the term "emergence" has always been related to the fact that one "whole" is not the same as "the sum of its parts". Now what is called "emergence" is the existence - and not only the uprising seen as a temporal process, as suggested by the word - of systems's unique characteristics which only exist under certain conditions. In general, this happens when a parameter regulating the intensity of the interactions surpasses a critical level. Hence, emergence is a punctuated and critical process of bifurcation. In other words, it is a process that makes one system, which is a possible set of characteristics, become another possible set of characteristics. In these cases the "agents" remain the same, but space-time organization is rather different before and after 
the bifurcation. But it is important to notice that "before and after" does not necessarily indicate here a difference in time. As well as "before and after", one could have said "below and above" the critical level.

\section{Conclusion}

The new rurality phenomenon, whose first Italian manifestations were reported in the second section of this article, corresponds to the appearance of unique characteristics in a system that can only exist under certain circumstances. Only in situations of great socioeconomic prosperity do the unique characteristics of this rurality show up. They are situations capable of simultaneously impelling the three vectors: biodiversity conservation; an economic utilization of its effects in terms of landscape architecture through several forms of "tourism", and a change in the energy matrix through the increase of its renewable sources. For that reason, it must be considered new, and not renascent.

It is new and not "emergent", because an "emergence" may result from any of the three types of opposition previously mentioned: antagonistic, undulatory, and embryonic. At least this is the conclusion that may be drawn from the comparison between the contribution of natural scientists Janine Guespin-Michel and Camille Ripoll (2005) and the ensuing philosophical essay by Lucien Sève (2005). Hence the necessity to emphasize that the new rurality phenomenon does not correspond to the first two kinds of dialectical opposition presented respectively in Lefebvre's (antagonistic) and Kayser's (undulatory) hypothesis, but rather to the third type, the embryonic character.

Up to the end of the $20^{\text {th }}$ century, the dynamics of rural regions in the most developed countries was determined by primary sector productive activities whose viability was always dependant on the exportation to markets located essentially in cities. And the labor force that became redundant with the increase in productivity also had an urban destiny. From a certain critical level achieved by this process, there appears in parts of these rural regions a dynamic that comes to be determined by markets corresponding to new forms of consumption. They are forms that result from the "diffusion in space of the effects of modernization and enrichment of society as a whole", in Kayser's words. However, this does not reduce, and sometimes rather intensifies, the ecological contradiction between the rural and the urban phenomena. There remains the detachment process between the cities and the natural ecosystems, which turn the former into the antinature par excellence, in the words of the great biologist Samuel Murgel Branco (1989, p. 109):

Everything that is produced by human invention and ingenuity is artificial, and necessarily opposed to what is natural. Consequently, the city, where this greater level of "artificialness" is reached, represents the opposite to the natural, in a proportional measure to the cultural characteristics of the population inhabiting it [...]. The city, despite being an environment, does not constitute a true ecosystem, since it does not comprehend an activity of production or fixation of primary energy. 
In short, the artificialization level of ecosystems is the ultimately distinguishing point between the urban and rural. And this is why instead of an urban revolution predicted by Lefebvre, or a rural rebirth, preferred by Kayser, what we witness, in the beginning of the $21^{\text {st }}$ century, is the birth of another rurality.

And last, but not least, we should remember that in the conclusion of the already classical The Death and Life of Great American Cities (Jacobs, 1989) a kind of prophecy was made about the pacific urban-rural coexistence. Certainly, Jane Jacobs was absolutely right when she said that cities need to have rural areas near them, and that rural areas need the cities' diverse opportunities and productivity. But she has added: "so that human beings can be in a position to appreciate the rest of the natural world instead of to curse it" (ibidem, p. 445). So, as seen in the second section, in the new rising rurality, precisely because it is appreciated and not cursed, we can already identify a range of conflicts whose characteristics could not even been half-seen in 1961.

\section{Notes}

1 Published in Estudos Avançados (n. 51, p. 51-67, maio-agosto 2004), has been awarded the II Prêmio Milton Santos, granted in May 2005 by Associação Nacional de Pesquisa e Pós-Graduação em Planejamento Urbano e Regional (Anpur)

2 This information was obtained during my stay in Italy in April-June 2005, thanks to an extremely used grant from Fapesp.

3 From "Confessions of a Humanistic Naturalist", in: Gould (1998, p. 1-2).

4 This elegant synthetic formula was proposed by Bertrand Hervieu and Jean Viard (2001).

5 Of course there are exceptions, mainly in North America, where centers of rural development are induced by peculiar investments either public (such as prisons), or private (such as casinos). However, these exceptions only confirm the general rule according to which rural dynamism in mature societies is caused mainly by the economic exploration of natural and cultural amenities. For this reason, the virtuous present rurality of the First World is the one that has managed to go through the last century without being jeopardized by some of the numberless negative environmental impacts effected by primary and secondary activities, resulting from the most obvious comparative advantages.

6 More detailed information about these three vectors can be found in "Destinos da ruralidade: um zoom sobre a Itália", presented at XXIX Encontro Nacional da ANPOCS". (Caxambu, MG, 25.10.2005) and at VI Encontro Bienal da ECOECO (Brasília, DF, 24.11.2005), available at: <www.econ.fea.usp.br/zeeli/>.

7 Also deserving mention is the "Fondazione Slow Food per la Biodiversità", created in 2002 by the international movement of the same name, whose origins trace back to Piemonte in the beginning of the 1980s (Petrini, 2005).

8 Or demanding a Herculean conquest for such activities, as shown by the vines and olive groves cultivated in "terraces", that today are a typical mark of the "Cinque Terre" National Park, declared by Unesco as a Patrimony of Mankind in 1997. 
9 There is a project aiming at the conversion of beet sugar production into biofuel. But this proposal still must be approved by the European Parliament.

10 Which does not apply to the older ones, such as the hydroelectric sources.

11 "Italia Nostra" is an 50-year-old entity, presided since 1988 by the Countess Desideria Paolina dall'Onda, essentially dedicated to the "tutorship of the nation's historical, artistic and natural patrimony". It is one of the most active environmental organizations in the field of "territory governance".

12 A similar comment could be made about the speculation on a rural-urban continuum. This expression aims to contradict the idea of a qualitative discontinuity between urban and rural. And there must be no better examples of this way to approach the issue than the collectanea organized by Champion \& Hugo (2003), whose subtitle speaks for itself: "Beyond the urban-rural dichotomy".

13 For example: Cirne-Lima (1996, 2002), Oliveira (1999), Cirne-Lima e Rohden (2003), Cirne-Lima et al. (2004) e Oliveira (2004), of the traditional Dialectics. The concise exposition of the analytical tradition made by Marcondes $(2005$, p. 51$)$ advocates for an approximation with the critical theory of the School of Frankfurt, and also with the structuralist view, "among others". In the same direction, Pinto (2003, p. 58), attempts "an acceptable conciliation between formal logic, dialectical tensions and a systemic approach". Such positions are opposed to those of more "radical" analytical thinkers like Gianetti (2004).

14 It was mainly the reading of the most recent works by philosophers, like Étienne Balibar, Etifichios Bitsakis, Lucien Sève and Roberto Cirne-Lima, that has engendered the formulation prsent in this paragraph, although it is not possible to say that the reflection corresponds precisely to the thought of any one of them. It is worth noticing that Hegel used the word Aufheben, that has a threefold sense: a) to dissolve, to undo, or to annul; b) to keep; c) to put in a higher place, to place above. These three senses occur in the formation of the "synthesis". In the first, the opposition of the poles is overcome and annulled. And the excluding character that existed between thesis and antithesis is dissolved and disappears. In the second sense, the poles are preserved and maintained in everything positive they had, despite the dissolution. And in the third sense, a higher level is reached: in the unity of the synthesis there is ascension to a superior level. (Cirne-Lima, 2002, p.125),

15 It should be registered, however, that the title of Cloke's article is "Counterurbanization", and that he used, according to Kayser himself, expressions such as "regeneration" of rural zones or rural "resurgence".

16 In the original: "la reprise de croissance dans le monde rural pris globalement, comme dans les bourgs et petites villes, est le résultat de la diffusion dans l'espace des effets de la modernisation et de l'enrichissement de l'ensemble de la societé".

17 In the original: "Faisant l'analyse des mutations contemporaines enregistrées dans les campagnes du monde occidental, ce livre permet de vérifier ce qui n'était à l'origine que l' hypothèse d'un observateur attentif: la renaissance. L'expression n'est pas le produit d'une imagination poétique: elle est reprise de la littérature scientifique américaine actuelle. Nous l'avions d'ailleurs employée ingénuement dès 1972 dans un article collectif, à propos des menaces que faisait peser sur le plateau du Larzac le projet d'extension du camp militaire".

18 After the dedication, Kayser chooses the following passage as an epigraph for his book: "S'il est vrai que la communauté paysanne peut aujourd'hui renaître, en fonction 
d'exigences et sur des bases modernes, rien de plus intéressant que cette renaissance, - d'où sortira peut-être un sens nouveau de la terre." Henri Lefebvre, 1949. (Kayser, 1990 , p. 5, emphasis in the original). This is the last paragraph of a famous text from the phase when Lefebvre was a rural sociologist. Its Portuguese translation by Wanda Caldeira Brandt is in Martins (1986): "Se é verdade, ademais, que a comunidade camponesa pode, hoje, renascer, em função de exigências e sobre bases modernas, nada mais interessante que este renascimento - do qual sairá, talvez, um novo sentido da Terra!" ["If it is true, moreover, that the peasant community can, today, resurge, as a function of demands and on modern bases, nothing is more interesting than this rebirth - from which will rise, perhaps, a new sense of the Earth!”] (Lefebvre, 1949, p.162). In Kayser's book epigraph, the " $t$ " in "Terre" (Earth) is not a capital letter and there is no exclamation point either.

19 The reflections in the three following paragraphs are based on Guespin-Michel e Ripoll (2005). Especially pages 16, 27, 42 and 44. See also Foley (2003).

\section{Bibliography}

ADORNO, T. W. Introdução à controvérsia sobre o positivismo na sociologia alemã. São Paulo: Nova Cultural, 1999. (Os pensadores).

BALIBAR, É. La philosophie de Marx. Paris: La Découverte, 2001.

BARBERIS, C. Turismo e nuova ruralità. In: TCI - Touring Club Italiano. Turismo e mondo rurale. Atti del convegno (Ragusa-Modica - November 23-25 1989). Milano: TCI, 2001. p.33-46.

BATTILANI, P. Vacanze di pochi vacanze di tutti. L'evoluzione del turismo europeo. Bologna: Il Mulino, 2001.

BITSAKIS, E. Le nouveau réalisme scientifique. Paris: L'Harmattan, 1997.

La nature dans la pensée dialectique. Paris: L'Harmattan, 2001.

BONAPACE, U. I valori della ruralità nel mondo attuale. In: TCI - Touring Club

Italiano. Turismo e mondo rurale. Atti del convegno (Ragusa-Modica - November 23-25.

Milano: 1989). Milano: TCI, 2001. p.23-32.

BRANCO, S. M. Ecossistêmica: uma abordagem integrada dos problemas do meio ambiente. São Paulo: Edgard Blücher, 1989.

. Meio ambiente e biologia. São Paulo: Senac, 2001.

CARANDINI, G. Un altro Marx. Lo scienziato liberato dall'utopia. (Prefazione di Giorgio Ruffolo). Roma: Laterza, 2005.

CHAMPION, T.; HUGO, G. (Ed.) New forms of urbanization: beyond the urbanrural dichotomy. International Union for the Scientific Study of Population (IUSSP) \& Ashgate, 2003.

CIANCIULLO, A. Energia pulita, la battaglia del vento. La Repubblica, June 14th TCI, 2005a. p.31.

. L'Italia a caccia di energia pulita. La Repubblica, June 21st 2005b, p.28.

. Via libera alle centrali eoliche. La Repubblica, June 28th 2005c, p. 25.

CIPOLLA, C. M. Before the industrial revolution: European society and economy 10001700. 3.ed. London: Routledge, 1993.

CIRNE-LIMA, C. Sobre a contradição. Porto Alegre: s. n., 1996. 
CIRNE-LIMA, C. Dialética para principiantes. São Leopoldo, RS: Unisinos, 2002.

CIRNE-LIMA, C.; ROHDEN, L. (Org.) Dialética e auto-organização. São Leopoldo, RS: Unisinos, 2003.

CIRNE-LIMA, C. et al. (Org.) Dialética, caos e complexidade. São Leopoldo, RS: Unisinos, 2004.

CLOKE, P. Counterurbanization. Geography, n.1, 1985.

DAWKINS, R. A escalada do monte improvável. Uma defesa da teoria da evolução. São Paulo: Companhia das Letras, 1998.

DUBY, G. Guerriers et paysans. VII-XIIè siécles. Premier essor de l'économie européenne. Paris: Gallimard, 1973.

FOLEY, D. K. Complexity, self-organization, and political economy. Introdução. In: Unholy trinity: labour, capital and land in the new economy. London: Routledge, 2003.

GIANNETTI, E. Humildade analítica, arrogância dialética. Entrevista a Caio Caramico Soares. Folha de S.Paulo, São Paulo, May 5th 2004, Caderno Mais!, p.13.

GOULD, S. J. Leonardo's Mountain of Clams and the Diet of Worms: Essays on Natural History. New York: Three Rivers Press, 1998.

GUESPIN-MICHEL, J.; RIPOLL, C. Systèmes dynamiques non linéaires, une approche de la complexité et de l' emergence. In: SÈVE, L. Émergence, complexité et dialectique (avec Janine Guespin-Michel et al.). Paris: Odide Jacob, 2005.

HERVIEU, B.; VIARD, J. Au bonheur des campagnes. 2.ed. Paris: L'Aube Intervention, 2001 .

HESS, R. Henri Lefebvre et l'aventure du siècle. Paris: Métailié, 1988.

JACOBS, J. The Death and Life of Great American Cities. New York: Random House, 1989. (First edition 1961).

KAYSER, B. La renaissance rurale. Sociologie des Campagnes du Monde Occidental (1990). Paris: Armand Colin, 1990.

LE GOFF, J. O apogeu da cidade medieval. São Paulo: Martins Fontes, 1992.

LEFEBVRE, H. Problemas de sociologia rural. Translation by Wanda Cardeira Brandt of the article "Problèmes de sociologia rurale: la communauté paysanne et ses problèmes historico-sociologiques". Cahiers Internationaux de Sociologie, v.VI, p.78-100, 1949. Reprinted in Henri Lefebvre, Du rural à l'urbain (Paris: Anthropos, 1970, p.21-40). . The production of space. Oxford: Blackwell, 1995. . A revolução urbana. Belo Horizonte: Editora UFMG, 2002.

LEGAMBIENTE. Le Regioni Italiane davanti alle sfide della sostenibilità. (Rapporto sulla sostenibilità delle Regioni italiane realizzato in colaborazione com l'Istituto di Ricerca Ambiente Italia). Roma: Legambiente, Feb. 2005a.

LEGAMBIENTE. Idee e Proposte per rilanciare le Fonti Rinnovabili in Itália. Roma: Legambiente: Feb. 2005b.

MARCONDES, D. Filosofia analítica. Rio de Janeiro: Jorge Zahar Editor, 2004.

MARTINS, J. de S. (Org.) Introdução crítica à sociologia rural. São Paulo: Hucitec, 1986.

OCDE - Organization for Economic Co-operation and Development. Examens territoriaux de l'OCDE; Sienne, Italie. Paris: OCDE, 2002.

OLIVEIRA, M. A. de. Dialética hoje: lógica, metafísica e historicidade. São Paulo: Edições Loyola, 2004 
OLIVEIRA, M. B. de. Da ciência cognitiva à dialética. São Paulo: Fapesp e Discurso Editorial, 1999.

TCI - Touring Club Italiano. Turismo e mondo rurale. Atti del convegno (RagusaModica - 23-25 November 1989). Milano: TCI, 2001.

PETRINI, C. Slow Food Revolution. Da Arcigola a Terra Madre. Una nuova cultura del cibo e della vita. Conversazione com Gigi Padovani. (Prefazione di Vandana Shiva). Milano: Rizzoli, 2005.

PINTO, P. R. M. Dialética, lógica formal e abordagem sistêmica. In: CIRNE-LIMA, C.; ROHDEN, L. (Org.) Dialética e auto-organização. São Leopoldo, RS: Unisinos, 2003. p.57-106.

SÈVE, L. Sciences et dialectiques de la nature. Paris: La Dispute, 1998.

De quelle culture lógico-philosophique la pensée du non-linéaire a-t-elle besoin?. In: Émergence, complexité et dialectique (avec Janine Guespin-Michel et al.). Paris: Odide Jacob, 2005.

VEIGA, J. E. Destinos da ruralidade no processo de globalização. Estudos Avançados, São Paulo, v.18, n.51, May-Aug. 2004.

WANDERLEY, M. de N. B. A emergência de uma nova ruralidade nas sociedades modernas avançadas - o "rural" como espaço singular e ator coletivo. Estudos Sociedade e Agricultura, n.15, p.87-146, Oct. 2000.

ABSTRACT - THIS ARTICLE argues that Lefebvre (1970) and Kayser $(1972,1990)$ were both mistaken about the destiny of rurality. Empirical evidences from Italy do not confirm extreme conjectures on "complete urbanization" or "rural renaissance". And a kind of hermeneutics of these two hypothesis helps to build upon a third which intends to surpass them.

KEYWORDS - Rurality, Rural Development, Urbanization, Counter Urbanization, Henri Lefebvre, Bernard Kayser.

José Eli da Veiga is full professor of the Department of Economics at the School of Economics, Business Administration and Accountancy (FEA) of the University of São Paulo. Website: <www.econ.fea.usp.br/zeeli> @ - zeeli@usp.br

Translated by Lenita Esteves and Almiro Pisetta. The original in Portuguese is available at http://www.scielo.br/scielo.php?script=sci_issuetoc\&pid=0103-401420060002\&lng=p t\&nrm=iso.

Received on 1.15.2006 and accepted on 4.5.2006. 